\title{
DEMOGRAPHIC DATA AND FIGURES DERIVED FROM ESTONIAN IRON AGE GRAVES
}

\author{
RAILI AllmäE \\ Archaeological Research Collection, Tallinn University, Tallinn, Estonia
}

\begin{abstract}
Three Iron Age cremation graves from south-eastern Estonia and four graves including cremations as well inhumations from western Estonia were analysed by osteological and palaeodemographic methods in order to estimate the age and sex composition of burial sites, and to propose some possible demographic figures and models for living communities.

The crude birth/death rate estimated on the basis of juvenility indices varied between $55.1 \%$ and $60.0 \%$ ( $58.5 \%$ on average) at Rõsna village in south-eastern Estonia in the Middle Iron Age. The birth/death rates based on juvenility indices for south eastern graves varied to a greater degree. The estimated crude birth/death rate was somewhat lower $(38.9 \%$ ) at Maidla in the Late Iron Age and extremely high (92.1\%) at Maidla in the Middle Iron Age, which indicates an unsustainable community. High crude birth/death rates are also characteristic of Poanse tarand graves from the Pre-Roman Iron Age $-92.3 \%$ or the $1^{\text {st }}$ grave and $69.6 \%$ ofor the $2^{\text {nd }}$ grave. Expectedly, newborn life expectancies are extremely low in both communities - 10.8 years at Poanse I and 14.4 years at Poanse II. Most likely, both Maidla I and Poanse I were unsustainable communities.

According to the main model where the given period of grave usage is 150 years, the burial grounds were most likely exploited by communities of 3-14 people. In most cases, this corresponds to one family or household. In comparison with other graves, Maidla II stone grave in western Estonia and Rõsna-Saare I barrow cemetery in south-eastern Estonia could have been used by a somewhat larger community, which may mean an extended family, a larger household or usage by two nuclear families.
\end{abstract}

Keywords: grave; inhumation; cremation; burials; demography; population size; Iron Age 


\section{INTRODUCTION}

Inhumation and cremation burials were both common in Iron Age Estonia; however, the pattern which burials were prevalent has regional as well temporal peculiarities. In Estonia, cremation burials appear in the Late Bronze Age (1100-500 BC), for example, in stone-cist graves and ship graves, although inhumation is still characteristic of the period $[28,18]$. Cremation burials have occasionally been found beneath the Late Bronze Age cists and the Early Iron Age (500 BC-450 AD) tarand graves [30, 28]. In south-eastern Estonia, including Setumaa, the tradition to bury cremated human remains in pit graves also appeared in the Bronze Age and lasted during the Pre-Roman period (500 BC-50 AD) and the Roman Iron Age (50-450 AD), and even up to the medieval times $[30,23,33,9]$. During the Early Iron Age, cremations appear in cairn graves and have occasionally been found in many Pre-Roman early tarand graves where they appear with inhumations $[27,28,19,20,21$, $22,24]$. In Roman Iron Age tarand graves, cremation as well inhumation were practiced [28, 36, 37]; however, cremation was the prevailing burial practice during the Roman Iron Age, for example, in tarand graves in south-eastern Estonia [30, 28]. Roman Iron Age (50 AD-450 AD) burial sites have not been found in continental west Estonia [28, 38]). At the beginning of the Middle Iron Age (450-800 AD), burial sites, for example stone graves without a formal structure, like Maidla I, Lihula and Ehmja 'Varetemägi', appear in Läänemaa, west Estonia; in these graves cremations as well inhumations have been found $[39,48]$. Like underground cremation burial, the stone grave without a formal structure was the most common grave type during the Late Iron Age (8001200 AD) in west Estonia [39, 35, 48]. In south-eastern and eastern Estonia, sand barrows with cremation burials appeared at the beginning of the Middle Iron Age. Cremation barrows are attributed to the Culture of Long Barrows and are most numerous in the villages Laossina and Rõsna in northern Setomaa, on the western shore of Lake Peipsi $[8,48]$. Apparently during the Iron Age, the practiced burial customs varied in Estonia.

However, cremation, inhumation or mixed and fragmentary bone material from graves, we have scarce data on the communities who used these graves. In the present paper, the results of osteological and demographic analyses of seven skeletal samples are presented: Poanse I and II tarand graves from the Early Iron Age, Maidla I stone-grave and Rõsna sand-barrow cemeteries from the Middle Iron Age and Maidla II stone-grave from the Late Iron Age. The aim of this paper was to estimate the number of burials in seven Estonian Iron Age graves, to assess the biological age at death and the sex of the deceased in order 
to get some demographic figures for these past populations and to model the size of living communities who used these graves during the Iron Age.

\section{MATERIAL AND METHODS}

The material comes from Pre-Roman (500BC-50AD), Middle (450-800 AD) and Late Iron Age (800-1250 AD) graves.

Poanse tarand graves with inhumation burials at West Estonia were excavated by Mati Mandel in the 1970s [38] and were dated to the Early Iron Age. Poanse I tarand grave was established in the middle of the Pre-Roman Iron Age, the archaeologically estimated time-span when grave was in use is approximately $250 \mathrm{BC}-50 \mathrm{AD}$. Poanse II tarand grave was established somewhat later, at the end of the Pre-Roman Iron Age, and the time-span when grave was in use is shorter, approximately 150 years $[27,28]$. Human skeletal remains from Poanse tarand graves were osteologically analysed by Jonathan Kalman [22].

The stone graves of Maidla I ( $5^{\text {th }}-6^{\text {th }}$ centuries AD, Middle Iron Age) and Maidla II $\left(10^{\text {th }}-13^{\text {th }}\right.$ centuries AD, Late Iron Age) were excavated by Mati Mandel between 1983 and 1985, and between 1987 and 1990; the graves contained inhumation as well as cremation burials [39]. The human skeletal remains from these graves were osteologically analysed by the author; the radiocarbon dates of the cremated and inhumated bones from these graves confirm the archaeochronological datings $[1,2,3,4,5,7]$.

Suure-Rõsna, Rõsna-Saare I and II sand-barrow cemeteries with cremation burials from the second half of the $1^{\text {st }}$ millennium AD were excavated by Mare Aun during the 1980s. Rõsna-Saare I cemetery consisted of ten barrows, Rõsna-Saare II cemetery of eleven barrows and Suure-Rõsna of ten barrows, six of which were excavated [8]. The cremated bones from these graves were osteologically analysed by the author. The samples of the cremated bones were radiocarbon dated in order to specify the time-span when the grave was in use. The results of these analyses were in accordance with archaeochronological datings but indicated the possible earlier establishment of these burial sites [4, $5,6,7]$.

In order to estimate the minimum number of individuals in a grave, numerous different recurrent bone fragments were recorded; however, the pars petrosa of os temporale as the most frequently found element was the best unit for calculating the MNI. The plausible number of individuals (PNI) was estimated on the basis of fragments ( 20 or more) of the cranial vault combined with at least one determined fragment of the human skeleton. The cranium was preferred 
because the fragments are easily determinable amongst cremated bones, and most likely full corpses were cremated. To estimate the PNI minimum number of burials, distances between bone units, their colour, the bone morphology indicating the age and sex of the buried individuals, and other archaeological/ osteological information was taken into account.

The sex and age at the death of the deceased were determined according to common osteological standards $[10,13,14,15,40,50]$. No archaeological gender assessments were available during biological sex and age assessment.

To assess the biological sex of the cremated adult individuals, the morphological traits of the occipital bones (external occipital protuberance, nuchal lines), the temporal bones (mastoid process, temporal line, zygomatic process), the frontal bones (superciliary ridge, supraorbital margin, temporal ridge, glabella), the zygomatic bones (frontal process), and the mandible (condylar process, mandibular ramus and angle, mental tubercules and protuberance) were used. In some cases, morphological traits on the post-cranial skeleton (for example muscle attachment areas of the long bones) were used as additional criteria; general robustness of skeletal elements was also observed.

To assess the age of the cremated individuals at death, the suture closure of cranial bones, the union of epiphyses and dental development were used. If applicable, other criteria were used to estimate or specify the age at death: the morphology of the cranial vault [45] and the morphology of tooth roots the roots of older individuals become more rounded due to the deposition of cementum - hypercementosis is quite common in older individuals $[46,52]$, which can also add data to attempts to determine the age. Age-related pathologies on cremated bones, for example osteoarthritis or osteophytosis on vertebrae or anywhere on skeletal elements, were also used. The assessment of the age of sub-adults is more reliable due to stages of epiphyseal fusion and dental development. The osteological age and sex assessments are conducted by the author, except for Pre-Roman Poanse skeletal samples, which were assessed by Jonathan Kalman [22].

Demographic estimations were performed using several methods. In our model, we assume that the population is stationary and that birth and death rates are equal (growth $=0$ ). The reason is that the Estonian populations under study were all too small-scale to model positive or negative natural increase.

Firstly, the method of life tables proposed by G. Acsádi and J. Nemeskéri [52] was used to estimate the life expectancy at birth $\left(\mathrm{e}^{0}{ }_{0}\right)$. Here, the natural data received from skeletal samples were used. 
Secondly, the life tables were corrected according to F. W. Rösing and R. Jankauskas [43], where the proportion of small children (0-4 years) in the population was increased to $45 \%$ of the total skeletal population under study. This means that $45 \%$ of the population died before they reached the age of 5 .

J. P. Bocquet and C. L. Masset $[11,12]$ established the third model used here to estimate the demographic figures of past populations. The ratio of sub-adults to adults or the juvenility index was also calculated for every population under study.

The newborn life expectancy, crude death rate $\left(1 / \mathrm{e}^{0}\right)$ and the size of living populations were calculated according to all the three models. In these models we assume that the population is stationary, i.e. birth and death rates are equal (growth $=0$ ).

Then, the fertility rate and the number of female offspring born per woman (GRR) was estimated from the juvenility indices of Boquet-Appel and Masset [12] and calibrated from R. McCaa [15, 16], and then the total number of offspring per woman (TFR) was calculated: GRR $\times 2.05=$ TFR.

The size of the living population was calculated according to the formula proposed by D. Ubelaker [49].

\section{RESULTS AND DISCUSSION}

The number of buried individuals in graves varies from 20 to 74 - not very big cemeteries in the number of identified burials (Table 1). The sex and age assessment often failed due to the character of the bone material which mostly consisted of cremated or/and fragmented human bones. However, the age structures of the burial sites under study show quite a representative proportion of subadults, from $29.7-45.7 \%$ of the total number of burials (Table 1). The masculinity indices show acceptable variation, probably referring to normal burial sites. The exceptions are Poanse graves; the first grave shows a higher number of female individuals, and in the second one the number of identified male burials exceeds females twice. The demographic characteristics of seven Estonian graves under study are presented in Table 1; life tables with raw and corrected data are not presented here because they have been published earlier [7].

Newborn life expectancy, calculated according to non-corrected life tables (raw data), indicates the highest values for graves and points to relatively low mortality. The data, corrected according to Rösing and Jankauskas [43], in which the proportion of infants and small children ( $0-4$ years) is increased to 
$45 \%$ of the total number of individuals, show lower and probably more reliable values for new-born life expectancy (Table 1). The model based on the juvenile ratio/index $[11,12]$ proposes the lowest new-born life expectancy.

The juvenility indices $\mathrm{D}_{5-14} / \mathrm{D}_{20+}$ for sand barrow cemeteries vary from 0.28 to 0.31 ( 0.30 for the summarised Rõsna village sample), $\mathrm{e}_{0}^{0}$ between 16.7 and 18.1 years (17.1 years for the summarised sample) indicating mortality between $55.1 \%$ and $60.0 \%$ ( $58.5 \%$ for the summarised sample). These mortality values are much higher in comparison with those received from non-corrected life tables (31-38\%) and slightly higher in comparison with the mortality obtained from corrected life tables (45-54\%o). New-born life expectancy at Rõsna village (summarised) during the Middle Iron Age was 17.1 years, crude death rate was $58.5 \%$ on average (Table 1 ), indicating relatively unfavourable living conditions in comparison with Late Iron Age Maidla.

The Maidla stone graves show higher variability in juvenility indices and new-born life expectancy (Table 1). The Maidla I grave indicates a very high crude death rate $(92.1 \%$ ) and extremely low new-born life expectancy $\left(\mathrm{e}^{0}=10.9\right)$ - conditions under which a community is hardly sustainable. For the Maidla II grave the mortality rate is the lowest (38.9\%o) and life expectancy at birth $\left(e_{0}^{0}=25.7\right)$ the highest in comparison with other communities under study.

The tarand graves of Poanse show similar figures with Maidla I stone grave - the crude death rate is very high, and life expectancy at birth is very low (Table 1). These unexpectedly high death rates could indicate that the model based on juvenility indices is not suitable for these communities. There could be many reasons, for example that this indicator responds to changes in the rates of population growth, changing the structure by age in the direction of categories of younger age, and therefore raising the rate of infantile deaths [41].

We should also bear in mind that Maidla I is a very small grave (only 20 burials), and that in Maidla II grave the older children (over 5 years) could also be under-represented as well as infants, as only two cremations of sub-adults were detected in the grave [1]. It is well known that the number of children dying in the age category of 5-14 years is sensitive to variation in population growth. The high juvenility index could indicate a stationary population with low life expectancy at birth, but it could also indicate an expanding population [44]. High juvenility indices of Poanse and Maidla I graves could indicate either option, but most likely they indicate a stationary population as we are dealing with burial sites of single families or households here $[1,5,17,22$; also see below] 


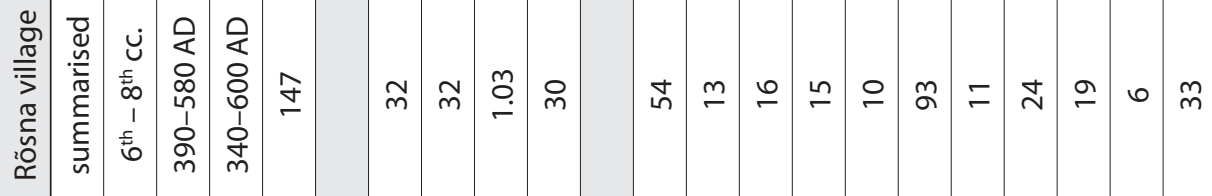

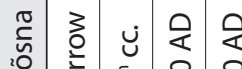

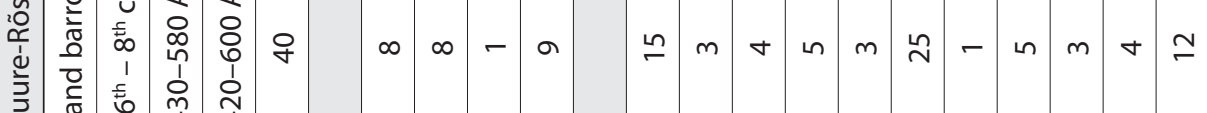

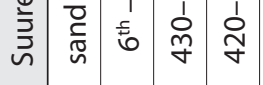

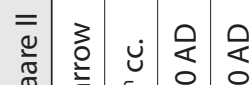

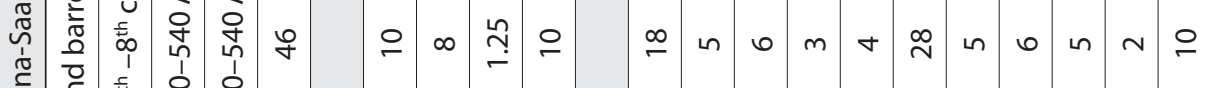

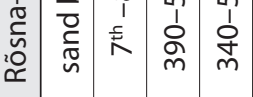

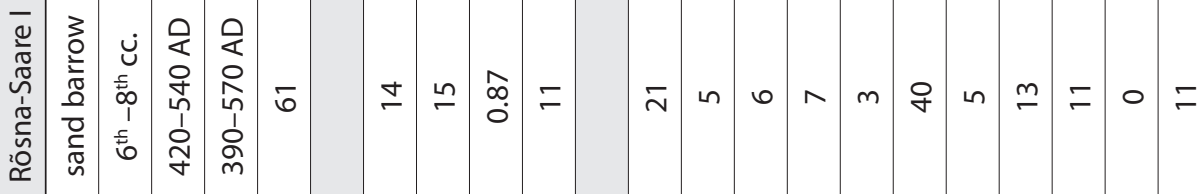

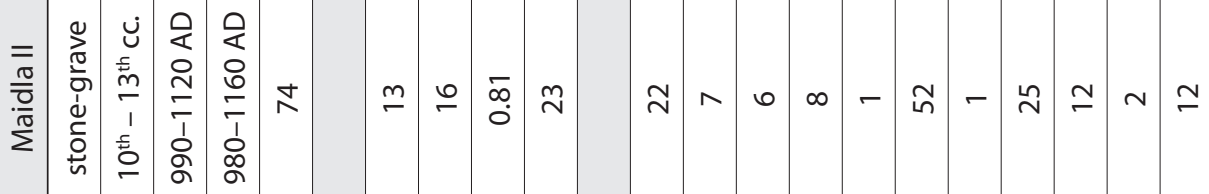

$$
\begin{aligned}
& \text { - }
\end{aligned}
$$

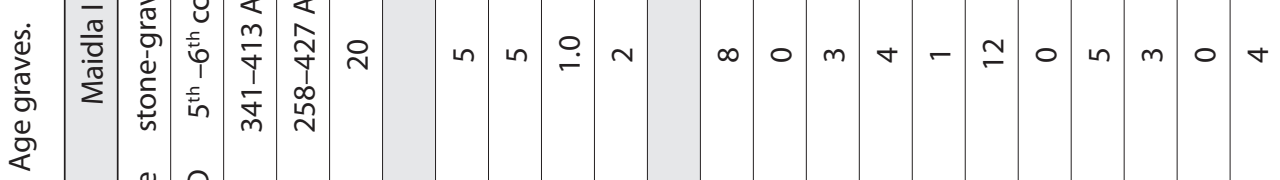

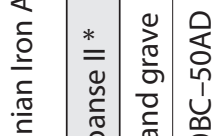

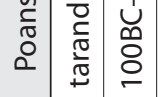

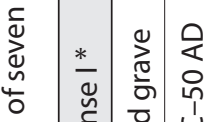

$$
\begin{aligned}
& \text { 离 }
\end{aligned}
$$

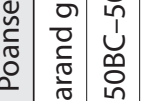

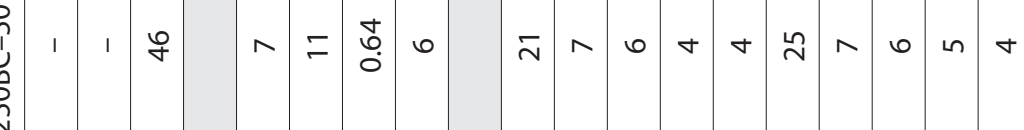

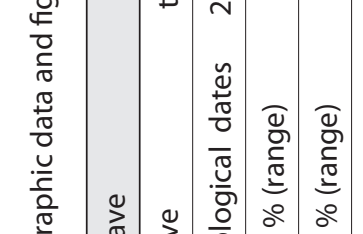

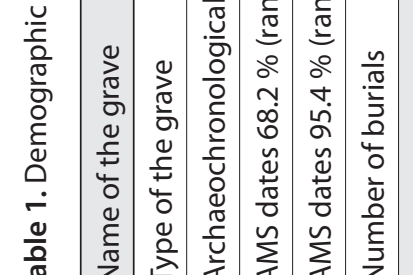

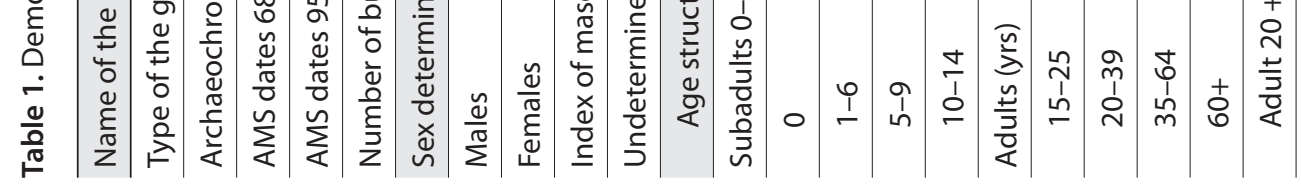




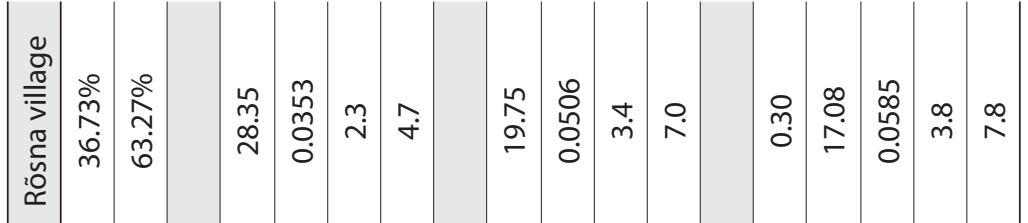

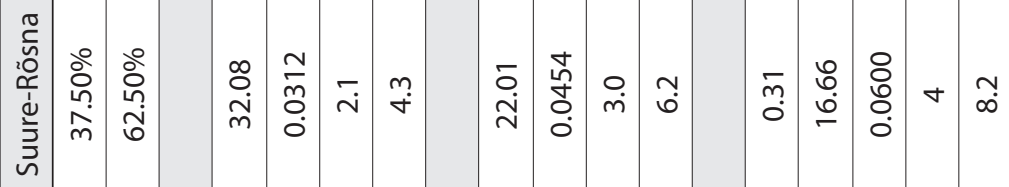

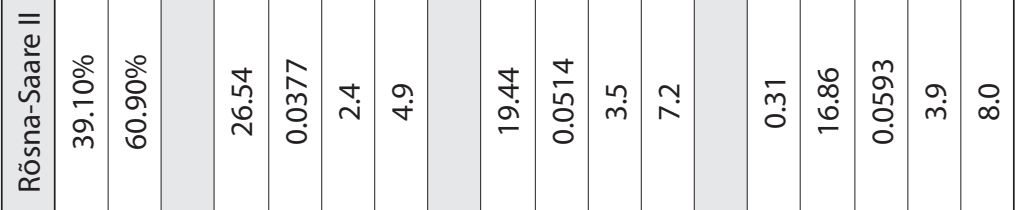

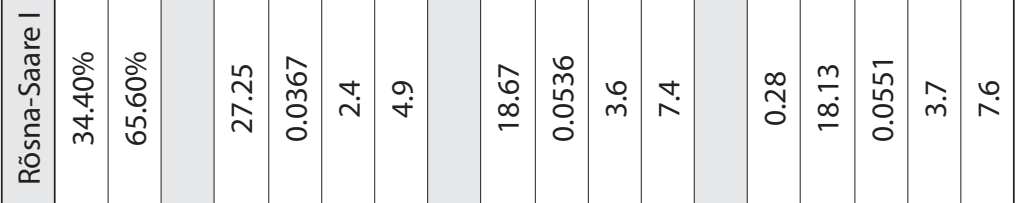

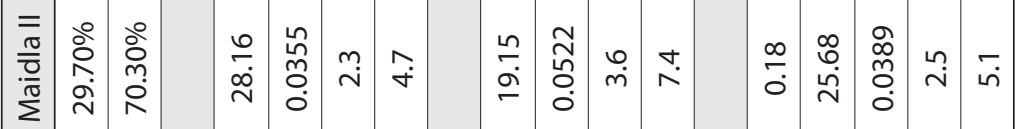

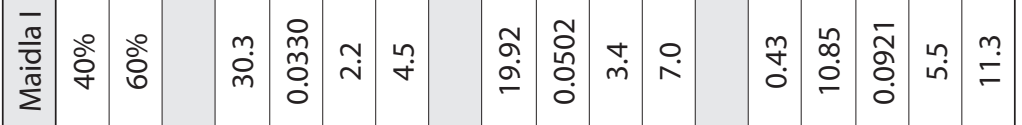

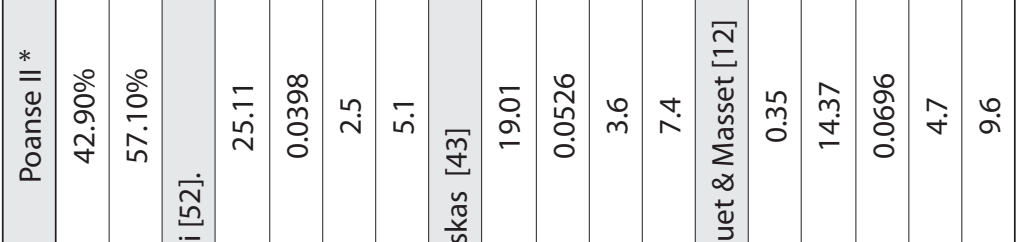

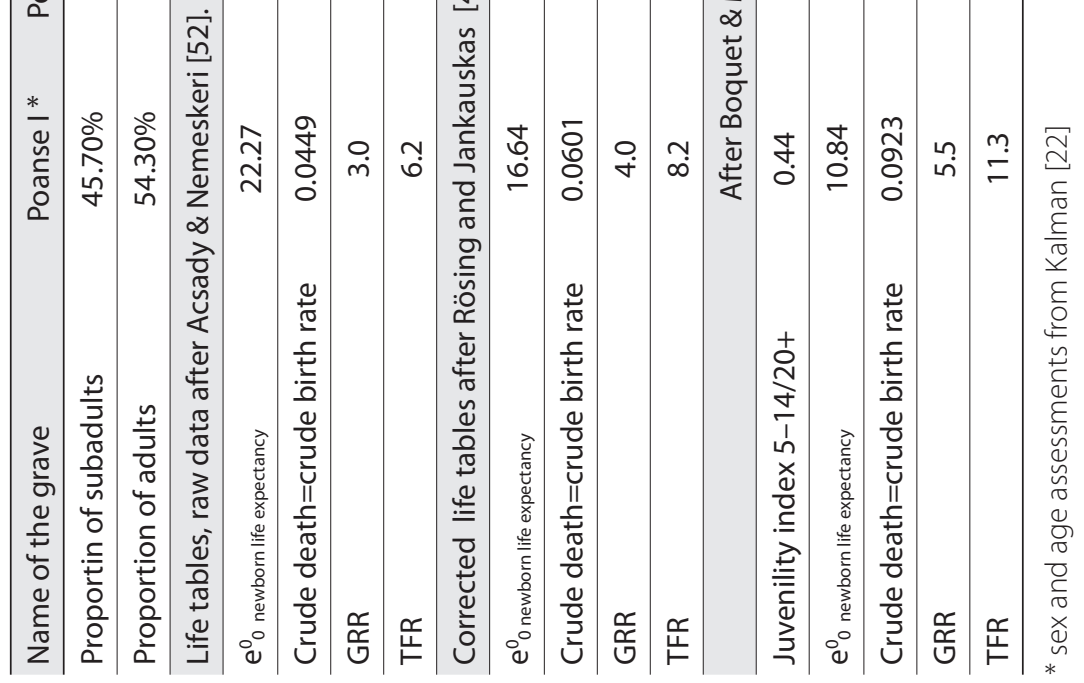


The received GRR and TFR fertility rates are presented in Table 1. According to the juvenility indices model, the lowest number of offspring is characteristic of women of Late Iron Age Maidla, and the highest of Maidla I (Middle Iron Age) and Poanse I (Early Iron Age) communities. The number of offspring increases with mortality as expected, because higher infant mortality reduces the birth interval. When a nursing child dies, the natural sterility due to the lactation period is interrupted and conception happens earlier [51]. Human reproductive strategies may change under the influence or interaction of several economic, social and biological factors. Fertility may increase, for example, during war, famine and drought, although the mortality rate is high at the same time. This phenomenon is observable in the material studied: low new-born life expectancy is related to a higher number of offspring.

To model the size of the living population, life expectancy at birth and the estimated time period of grave usage are the crucial variables. The estimated time period is usually given by the archaeologist according to the chronology of the artefacts in the grave. If the time period is not estimated, we can model the size of the living population for different time periods of grave use (Table 2). The main model, discussed below, is based on life expectancy derived from juvenility indices, and the average grave usage period is 150 years. According to this model, communities of 3-14 people were most likely to exploit the burial grounds. In most cases, it corresponds to one family or household. In comparison with other graves, Maidla II stone grave in western Estonia and RõsnaSaare I barrow cemetery in south-eastern Estonia could have been used by a somewhat larger community, which may mean an extended family, a larger household, or usage by two nuclear families.

Commonly, the archaeologist estimates the length of the time-period when the grave was in use.

Maidla I stone grave in west Estonia was probably established at the end of the Roman Iron Age or at the beginning of the Middle Iron Age [38]; the time period of grave use has not been estimated for Maidla I stone-grave. One family at most used the grave, and the crude death rate was very high $\left(\mathrm{e}_{0}{ }_{0}=10.9\right.$, derived from the juvenility index). This means that the community was probably not sustainable and perhaps inhabited the site for a short period only.

The same pattern characterises the Pre-Roman Iron Age tarand graves at Poanse. New-born life expectancies (derived from juvenility indices) are also very low here, at 10.8 and 14.4 years (Tables 1,2 ). 
Table 2. The calculated sizes of living communities.

\begin{tabular}{|c|c|c|c|c|c|c|c|c|c|}
\hline \multirow[t]{2}{*}{ Grave } & \multirow{2}{*}{$\begin{array}{c}\text { Number } \\
\text { of buri- } \\
\text { als }\end{array}$} & \multirow{2}{*}{$\begin{array}{c}\text { Life expec- } \\
\text { tancy at } \\
\text { birth in yrs }\end{array}$} & \multicolumn{7}{|c|}{ Grave usage in years and respective community size } \\
\hline & & & 350 & 300 & 250 & 200 & 150 & 100 & 50 \\
\hline \multirow{3}{*}{$\begin{array}{l}\text { Poanse I } \\
\text { tarand grave* }\end{array}$} & \multirow[t]{3}{*}{46} & 22.27 & 2.93 & 3.41 & 4.10 & 5.12 & 6.83 & 10.24 & 20.49 \\
\hline & & 16.64 & 2.19 & 2.55 & 3.06 & 3.83 & 5.10 & 7.65 & 15.31 \\
\hline & & 10.80 & 1.42 & 1.66 & 1.99 & 2.48 & 3.31 & 4.97 & 9.94 \\
\hline \multirow{3}{*}{$\begin{array}{l}\text { Poanse II } \\
\text { tarand grave* }\end{array}$} & \multirow[t]{3}{*}{35} & 25.11 & 2.51 & 2.93 & 3.52 & 4.39 & 5.86 & 8.79 & 17.58 \\
\hline & & 19.01 & 1.90 & 2.22 & 2.66 & 3.33 & 4.44 & 6.65 & 13.31 \\
\hline & & 14.37 & 1.44 & 1.68 & 2.01 & 2.51 & 3.35 & 5.03 & 10.06 \\
\hline \multirow{3}{*}{$\begin{array}{l}\text { Maidla } \\
\text { I stone grave }\end{array}$} & \multirow[t]{3}{*}{20} & 30.30 & 1.73 & 2.02 & 2.42 & 3.03 & 4.04 & 6.06 & 12.12 \\
\hline & & 19.92 & 1.14 & 1.33 & 1.59 & 1.99 & 2.66 & 3.98 & 7.97 \\
\hline & & 10.90 & 0.62 & 0.73 & 0.87 & 1.09 & 1.45 & 2.18 & 4.36 \\
\hline \multirow{3}{*}{$\begin{array}{l}\text { Maidla } \\
\text { Il stone grave }\end{array}$} & \multirow[t]{3}{*}{74} & 28.16 & 5.95 & 6.95 & 8.34 & 10.42 & 13.89 & 20.84 & 41.68 \\
\hline & & 19.15 & 4.05 & 4.72 & 5.67 & 7.09 & 9.45 & 14.17 & 28.34 \\
\hline & & 25.70 & 5.43 & 6.34 & 7.61 & 9.51 & 12.68 & 19.02 & 38.04 \\
\hline \multirow{3}{*}{$\begin{array}{l}\text { Rõsna-Saare I } \\
\text { sand- } \\
\text { barrow } \\
\text { cemetery }\end{array}$} & \multirow[t]{3}{*}{61} & 27.25 & 4.75 & 5.54 & 6.65 & 8.31 & 11.08 & 16.62 & 33.25 \\
\hline & & 18.27 & 3.18 & 3.71 & 4.46 & 5.57 & 7.43 & 11.14 & 22.29 \\
\hline & & 18.10 & 3.15 & 3.68 & 4.42 & 5.52 & 7.36 & 11.04 & 22.08 \\
\hline \multirow{3}{*}{$\begin{array}{l}\text { Rõsna-Saare } \\
\text { II sand-bar- } \\
\text { row } \\
\text { cemetery }\end{array}$} & \multirow[t]{3}{*}{46} & 26.54 & 3.49 & 4.07 & 4.88 & 6.10 & 8.14 & 12.21 & 24.42 \\
\hline & & 19.44 & 2.55 & 2.98 & 3.58 & 4.47 & 5.96 & 8.94 & 17.88 \\
\hline & & 16.90 & 2.22 & 2.59 & 3.11 & 3.89 & 5.18 & 7.77 & 15.55 \\
\hline \multirow{3}{*}{$\begin{array}{l}\text { Suure Rõsna } \\
\text { sand-barrow } \\
\text { cemetery }\end{array}$} & \multirow[t]{3}{*}{40} & 32.08 & 3.67 & 4.28 & 5.13 & 6.42 & 8.55 & 12.83 & 25.66 \\
\hline & & 22.01 & 3.84 & 4.48 & 5.37 & 6.71 & 8.95 & 13.43 & 26.85 \\
\hline & & 16.70 & 1.91 & 2.23 & 2.67 & 3.34 & 4.45 & 6.68 & 13.36 \\
\hline \multirow{3}{*}{$\begin{array}{l}\text { Rõsna } \\
\text { village } \\
\text { summarized }\end{array}$} & \multirow[t]{3}{*}{147} & 28.35 & 11.91 & 13.89 & 16.67 & 20.84 & 27.78 & 41.67 & 83.35 \\
\hline & & 19.75 & 8.30 & 9.68 & 11.61 & 14.52 & 19.36 & 29.03 & 58.07 \\
\hline & & 17.10 & 7.18 & 8.38 & 10.05 & 12.57 & 16.76 & 25.14 & 50.27 \\
\hline
\end{tabular}

* Poanse demographic data from Kalman [22]

** Life expectancy at birth from 1) non-corrected life tables and 2) corrected life tables after Rösing \& Jankauskas [43] 3) after Boquet-Appel \& Masset formula [12]. 
Valter Lang [26] has estimated the time period of grave use at Poanse I to have been 200-300 years and at Poanse II 150 years. Based on these estimations, the size of the living community who used Poanse I grave is 2 individuals and for Poanse II grave 3 individuals (Table 2). It is possible that our assumptions on the time-span of the grave usage periods are overestimated, mostly likely the graves at Poanse were used for a shorter period. Our idea that graves, especially tarand graves, were used for several centuries could be somewhat overestimated. For example, if we diminish the time span of grave use for Poanse I from 250 to 100 years and for Poanse II from 150 to 50 years, and use the new-born life expectancy derived from the juvenility index $\left(\mathrm{e}_{0}^{0}=10.8\right.$; $\mathrm{e}^{0}{ }_{0}=14.4$ years), we get another reality (Table 2 ). The size of the community for Poanse I grave is 5, and for Poanse II, it is 10.

During the Late Iron Age, a community of 7-10 individuals used the second Maidla grave in western Estonia - probably one family or household [3]. The estimated family size is in accordance with the earlier results of various authors on the average size of the Estonian family in the $13^{\text {th }}$ century and later periods [31, 42, 47]. M. Mägi [34] has argued that, for example, stone graves on Saaremaa island belonged to just one or two elite families.

The present study (grave was used for $\sim 250$ years) also suggests that probably one family or household ( $\sim 8$ individuals) had its own burial ground at Maidla during the $10^{\text {th }}-13^{\text {th }}$ centuries.

The results of osteological analysis of remains from the Middle Iron Age sand barrow cemeteries at Rõsna (south-eastern Estonia) indicate the same pattern - one family or household used one barrow cemetery. The assumptions on community size based on the archeologically determined number of burials (Rõsna-Saare I and Rõsna-Saare II) and a mortality rate of $40 \%$ o show similar results - barrow cemeteries should be regarded as the burial places of a single family, or at least a small group of people $[29,32]$. Similar results have been obtained from Iron Age east Lithuania: community sizes of 5-15 individuals usually buried their dead in one barrow cemetery. This number of individuals corresponds to a group of people of the size of an average nuclear family over several generations [29]. The models also suggest that, in comparison with other barrow cemeteries at Rõsna village, the Rõsna-Saare I cemetery might have been used by a somewhat larger household or extended family, or was used for a somewhat longer period. The calculated size of the living population is sensitive to the estimated time of grave use - according to these models, if the time span diminishes, the size of the calculated population will be larger (Table 2). 
The present study demonstrates that demographic figures depend on the model or sample chosen. The overall variability in the proportion of adults and sub-adults in graves is not striking, but when skeletal samples are very small, any minor change in the proportions of the age cohort has a significant impact on the demographic figures.

\section{REFERENCES}

1. Allmäe R. (2003). Läänemaa 5.-13. sajandi kalmete antropoloogiline aines. In: M. Mandel, Läänemaa 5.-13. sajandi kalmed. Töid ajaloo alalt, 5. Tallinn: Eesti Ajaloomuuseum, 243-262.

2. Allmäe R. (2004). Cremations of western Estonia in $5^{\text {th }}-13^{\text {th }} \mathrm{cc}$. In: International Scientific Conference "200 Years of Lithuanian Anthropology: Modern Trends, History, Relation to Medical Practice and Humanities". Vilnius. 26.

3. Allmäe R. (2006). Grave 2 of Maidla - the burial site of a single family. Estonian Journal of Archaeology, 10, 1, 3-23.

4. Allmäe R. (2013). Observations on Estonian Iron Age cremations. Archaeologia Baltica, 19, 31-47.

5. Allmäe R. (2014a). The demography of Iron Age graves in Estonia. Lietuvos Archeologija, 40, 103-120.

6. Allmäe R. (2014b). Rõsna kääbaskalmistud Põhja-Setumaal: põletusmatuste uuringutulemused. In: Ü. Tamla, V. Lang, eds.. Ajast ja ruumist. Uurimusi Mare Auna auks. Muinasaja teadus, 25. Tallinn. 39-50.

7. Allmäe R. (2017) Iron Age Cremation Burials In South-Eastern And West Estonia. An Osteological Approach. Dissertations On Humanities 37. Tallinn University. Tallinn. https://www.etera.ee/zoom/30646/view

8. Аун М. (1992). Археологичеческие памятники второй половины 1-го тысячелетия н.э. в Юго-Восточной Эстонии. Таллинн: Олион.

9. Aun M. (2009). Keskmine rauaaeg ja viikingiaeg (450-1050 pKr). In: M. Aun, ed., Setomaa, 2. Vanem ajalugu muinasajast kuni 1920. aastani. Tartu: Eesti Rahva Muuseum, 83-92.

10. Bass W. M. (2005). Human Osteology: A Laboratory and Field Manual. 5th edition. Missouri: Missouri Archaeological Society.

11. Bocquet J.-P., Masset C. (1977). Estimateurs en Paléodémographie. L’Homme, XVIII, 65-90.

12. Bocquet-Appel J.-P., Masset C. (1982). Farewell to paleodemography. Journal of Human Evolution, 11, 321-333.

13. Brothwell D. R. (1981). Digging up bones: The excavation, treatment and study of human skeletal remains. 3rd edition. London: Trustees of the British Museum. 
14. Buikstra J. E., Ubelaker D. H., eds. (1994). Standards for Data Collection from Human Skeletal Remains. Proceedings of a Seminar at the Field Museum of Natural History Organized by Jonathan Haas. Fayetteville: Arkansas Archeological Survey Research Series, 44. Arkansas Archeological Survey.

15. Mays S. (2006). The Archaeology of Human Bones. London, New York: Routledge.

16. McCaa R. (1998). Calibrating paleodemography: The uniformitarian challenge turned. American Association of Physical Anthropology Annual Meeting, April 2, 1998, Salt Lake City. http://www.hist.umn.edu/ rmccaa/paleo98/ index0.htm [Accessed 12.07.2018].

17. McCaa R. (2000). Paleodemography of the Americas. In: R. H Steckel, J.C. Rose, eds., The Backbone of History: Health and Nutrition in the Western Hemisphere. New York: Cambridge University Press, 94-126.

18. Jaanits L., Laul S., Lõugas V., Tõnisson E. (1982). Eesti esiajalugu. Tallinn: Valgus.

19. Kalman J. (2000a). Stone grave II of Tõugu - skeletal report. In: V. Lang, Keskusest ääremaaks. Viljelusmajandusliku asustuse kujunemine ja areng VihasooPalmse piirkonnas Virumaal. Muinasaja teadus, 7. Tallinn. 387-402.

20. Kalman J. (2000b). Tandemägi stone grave - osteological report. In: V. Lang, Keskusest ääremaaks. Viljelusmajandusliku asustuse kujunemine ja areng Vihasoo-Palmse piirkonnas Virumaal. Muinasaja teadus, 7. Tallinn: Ajaloo Instituut, 423-434.

21. Kalman J. (2000c). Uusküla II skeletal analysis. In: V. Lang, Keskusest ääremaaks. Viljelusmajandusliku asustuse kujunemine ja areng Vihasoo-Palmse piirkonnas Virumaal. Muinasaja teadus, 7. Tallinn: Ajaloo Instituut, 437-440.

22. Kalman J. (2000d). Skeletal analysis of the graves of Kaseküla, Poanse I and Poanse II. In: T. Tamla, ed., Eesti Ajaloomuusem. Töid ajaloo alalt, II. Tallinn: Eesti Ajaloomuuseum, 17-40.

23. Kiristaja A. (2009). Kiviaeg, pronksiaeg ja vanem rauaaeg. In: M. Aun, ed., Setomaa, 2. Vanem ajalugu muinasajast kuni 1920. aastani. Tartu: Eesti Rahva Muuseum, 23-67.

24. Kivirüüt A. (2014). A Comparative Osteological and Intra-Site Spatial Analysis of Tarand-Graves. MA dissertation. Tartu: University of Tartu. http://dspace.ut.ee/handle/10062/41912 [Accessed 24.04.2016]

25. Kurila L. (2009). The Social Organisation in East Lithuania in the $3^{\text {rd }}-12^{\text {th }}$ Centuries (on the Basis of the Mortuary Record) (Summary of doctoral dissertation). Vilnius: Vilnius University, http://vddb.library.lt/fedora/get/LT-eLABa-

26. Lang V. (1996). Muistne Rävala. Muistised, kronoloogia ja maaviljelusliku asustuse kujunemine Loode-Eestis, eriti Pirita jõe alamjooksu piirkonnas, I-II. Muinasaja teadus, 4. Tallinn: Eesti Teaduste Akadeemia Ajaloo Instituut. 
27. Lang V. (2006). Varased tarandkalmed Eestis. In: H. Valk, ed., Etnos ja kultuur. Uurimusi Silvia Laulu auks. Muinasaja teadus, 18. Tartu; Tallinn 53-78.

28. Lang V. (2007). The Bronze and Early Iron Ages in Estonia. Estonian Archaeology, 3. Tartu: Tartu University Press.

29. Lang V., Ligi P. (1991). Muistsed kalmed ajaloolise demograafia allikana. In: L. Jaanits, V. Lang, eds., Arheoloogiline kogumik. Muinasaja teadus, 1. Tallinn: Eesti Arheoloogiaselts, Eesti Teaduste Akadeemia Ajaloo Instituut, 216-238.

30. Laul S. (2001). Rauaaja kultuuri kujunemine Eesti kaguosas (500 e.Kr.-500 p.Kr.). Muinasaja teadus, 9 / Õpetatud Eesti Seltsi Kirjad, 7. Tallinn: Ajaloo Instituut, Õpetatud Eesti Selts.

31. Ligi H. (1961). Eesti talurahva olukord ja klassivõitlus Liivi sõja algul (15581561). Tallinn: ENSV Teaduste Akadeemia.

32. Лиги П. (1989). Культура длинных курганов в свете данных палеодемографии. Eesti Teaduste Akadeemia Toimetised, Ühiskonnateadused, 38, 4, 316-322.

33. Lillak A. (2009). Maa-alused põletusmatused Setomaal. In: M. Aun, ed., Setomaa, 2. Vanem ajalugu muinasajast kuni 1920. aastani. Tartu: Eesti Rahva Muuseum, 82.

34. Mägi M. (2002). At the Crossroads of Space and Time. Graves, Changing Society and Ideology on Saaremaa (Ösel), 9th-13th Centuries AD. CCC papers, 6. Tallinn: Institute of History/Gotland University College, Centre of Baltic Studies.

35. Mägi M. (2004). Changing trends in the study of Estonian Iron Age cemeteries: archaeological excavations in archives. In: G. Carver, ed., Digging in the Dirt: Excavation in a New Millennium. British Archaeological Reports, International Series, S1256. Oxford: Hadrian Books, 11-18.

36. Mägi, M. (2005a). Mortuary houses in Iron Age Estonia. Estonian Journal of Archaeology, 9, 2, 93-131.

37. Mägi M. (2005b). Kivikalmed ja surnumajad. Matmiskombestiku areng rauaaegsel Saaremaal. Saaremaa Muuseum. Kaheaastaraamat, 2003-2004. Kuressaare: Saaremaa Muuseum, 3-34.

38. Mandel, M. (2000). Poanse tarandkalmed. In: T. Tamla, ed., Eesti Ajaloomuusem. Töid ajaloo alalt, II. Tallinn: Eesti Ajaloomuuseum, 89-112.

39. Mandel, M. (2003). Läänemaa 5.-13. sajandi kalmed. Eesti Ajaloomuuseum. Töid ajaloo alalt, 5. Tallinn: Eesti Ajaloomuuseum, 1-242.

40. Miles A. E. W. (1963). Dentition in the assessment of individual age in skeletal material. In: D. R. Brothwell, ed., Dental Anthropology. New York: Pergamon Press, 191-209.

41. Muñoz A. (2015). The Use of Theoretical and Methodological Bases in Population Movement Studies: Paleo and Archaeo Demographic Approaches. In: A. Cucina, ed. Archaeology and Bioarchaeology of Population Movement among 
the Prehispanic Maya. Mexico: Universidad Autónoma de Yucatán Merida, 59-70.

42. Palli H. (1996). Eesti rahvastiku ajalugu aastani 1712. Academia, 6. Tallinn: Teaduste Akadeemia Kirjastus.

43. Rösing F. W., Jankauskas R. (1997). Infant deficit in pre-modern burial sites. In: M. Thetloff, ed., The 8th Tartu international anthropological conference. 12-16 October, Tartu, Estonia. Dedicated to the 100th Birth Anniversary of Prof. Juhan Aul. Tartu: University of Tartu, Centre for Physical Anthropology, 50-52.

44. Séguy I. Buchet L. (2013). Handbook of palaeodemography. INED Population Studies, 2. London: Springer.

45. Sigvallius B. (1994). Funeral Pyres. Iron Age Cremations in North Spånga. Theses and Papers in Osteology, I. Stockholm: Department of Archaeology, Osteological Research Laboratory, Stockholm University.

46. Soames J. V., Southam J. C. (1993). Oral Pathology. 2nd edition. Oxford: Oxford University Press.

47. Tarvel E. (1972). Adramaa. Eesti talurahva maakasutuse ja maksustuse alused 13.-19. sajandil. Tallinn: Eesti NSV Teaduste Akadeemia Ajaloo Instituut.

48. Tvauri A. (2012). The Migration Period, Pre-Viking Age, and Viking Age in Estonia. Estonian Archaeology, 4. Tartu: Tartu University Press.

49. Ubelaker D. H. (1989). Human Skeletal Remains: Excavation, Analysis, Interpretation. Manuals on Archeology, 2. 2nd edition. Washington: Taraxacum.

50. White T. D., Folkens P. A. (2000). Human Osteology. San Diego: Academic Press.

51. Wood J. W. (1990). Fertility in anthropological populations. Annual Review of Anthropology, 19, 211-242.

52. Acsádi G. Y., Nemeskéri J. (1970). History of Human Life Span and Mortality. Budapest: Akadémiai Kiadó.

\section{Address for correspondence:}

Raili Allmäe

Archaeological Research Collection

Tallinn University

Rüütli 6, Tallinn, Estonia 10130

E-mail: raili.allmae@tlu.ee 